\title{
VELLES IDEOLOGIES I NOVES REALITATS CORPORATIVISTES
}

\author{
Joan Martínez Alier \\ (Universitat Autònoma de Barcelona)
}

Aquest article analitza les ideologies sobre la distribució de la producció entre grups socials, i deixa fins al final les preguntes sobre què vol dir producció. La paraula corporativisme, com a ideologia i pràctica d'un sistema estructurat de desigualtat, lligada a socialdemocràcia, tal com faig en aquest article, pot semblar fins i tot una provocació. Cal explicar les raons per les quals la mateixa paraula fot aplicar-se a la ideologia del franquisme o del salazarisme i a la realitat d'estats com ara l'Estat espanyol d'ençà 1977 (i almenys fins el 1983).

Hom podria classificar el règim franquista com a exemple de corporativisme estatal. No hi havia llibertat d'associacio, i era obligatori d'ésser enquadrat dins d'un sindicat vertical, corporacions que agrupaven treballadors i empresaris del mateix ram. No hi havia partits polítics (a part de la Falange, després Movimiento Nacional), i les Cortes eren una Cambra corporativa (encara que alguns membres tenien una teòrica representació territorial).

Vull argumentar, tanmateix, que «corporativisme estatal» és una expressió contradictòria, almenys pel que fa a l'Estat espanyol franquista. Als territoris d'aquest Estat s'havia lliutat tecentment una guerta civil que fou una guerra de classes; la consciència de classe era molt forta. El corporativisme estatal és una ideologia política sense tealitat històrica? Potser el Peronisme a la seva primera època podria ser-ne un exemple, ja que els sindicats ho eren genuïnament; el dubte fóra si alguns altres interessos, con els exportadors agraris, van poder tenir representants autèntics. 
Per contestar la pregunta de si el franquisme és corporativisme estatal autèntic, analitzaré una mica la determinació de salaris i de condicions de treball. En el període $1939-1958$ els salaris i les condicions de feina van ésser determinats pel Govern per a cada ram de l'economia. Això no vol pas dir que no hi hagués mai cap vaga o d'altres formes de resistència, que donessin lloc a acords especffics d'empresa, malgrat que les vagues eren considerades delictes al Codi Penal. En general, tanmateix, les regulacions estatals eten implementades. Cal recordat la terrible desfeta soferta per la classe obreta (amb execucions massives encara els tres o quatre anys postetiors a la fi de la guerra); cal recordar també la crisi econòmica: els salaris reals no van atènyer els nivells d'abans de la guerra fins a meitat dels anys 1950 a la indústria $i$ fins als inicis dels 1960 a l'agricultura.

Tots els treballadors $\mathrm{i}$ empresatis pertanyien formalment als sindicats verticals. Els dirigents d'aquests «sindicats» eren designats pel Govern i exen obligatòriament membres de la Falange, no solament els de la part obrera sinó també els de la part empresarial, i sovint les pressions dels empresaris sobre el Govern no es canalitzaven pels sindicats verticals sinó a través de les Cambres de Comerç $\mathrm{i}$ d'Inđústria, que van continuar existint. Per dir-ho breument, un sindicat, els dirigents del qual són nomenats per I'Estat, és un sindicat mort, i el mateix s'aplica a una organització patronal.

La introducció d'una forma de negaciació collectiva el 1958 a tots els nivells, de centre de treball, empresa, local, província $\mathrm{i}$ «nacional», va fer paleses les contradiccions del «corporativisme estatal». El període de «primacia de l'economias i dels economistes va començat aleshotes quan Franco encara tenia gairebé vint anys per endavant, i encara no s'ha acabat. La teoria econòmica faxia servei com a ideologia de l'harmonia social, més convincent (fins i tot per als treballadors) que el «vell» corporativisme. La pèrdua d'influència de la Falange $i$ el paper jugat per grups catòlics, com ara l'Opus Dei i l'ACNP, fou parallel a aquests canvis d'ideologia.

Els catòlics creien en el "principi de subsidiarietat» de l'Estat. Abans de la guerra civil pensaven que podia arribar a haver-hi autèntics sindicats obrers catòlics, que farien convenis collectius dins de les "corporacions" amb els empresaris. Els salaris i les condicions de treball no tenien perquè ser regulats en detall per I'Estat.

L'any 1936, els catòlics s'haurien, sens dubte, estimat més una victòria electoral de la CEDA o un cop d'estat militar amb èxit que no pas una llarga guerra civil (que podien haver perdut). Haurien prohibit la CNT i possiblement també la UGT (que se n'havia anat cap a l'esquerra el 1934), haurien dissolt el Parlament i organitzat una Cambra corporativa. Els falangistes van guanyar ascendència durant la guerra $i$ ells no creien en absolut 
en el principi de «subsidiarietat». Tots ells van collaborar en la creació del «nou estat», i els catòlics van pagat el preu d'haver de posar-se l'uniforme Hluent de la Falange.

El 1946, Larraz, el ministre d'Hisenda, membre de l'ACNP, es va queixar amargament del «maltractament» (de curta durada) del règim de Franco pels Aliats. En l'hota de passió que viviem, molts deien que un règim corporatiu era una idea que pertanyia al totalitarisme, condemnable a priori. N'hi havia alguns que volien fer del tègim corporatiz una mena de criminal de guerra. Això era ignorància pura. Un règim corporatiu donava forma orgànica a l'estructura professional de la societat, eta un producte natural i espontani de la vida social que el dret positiu no podia tebutjar; calia fer que coincidís amb el bé comú. Després de la liquidació amb rebaixes que el liberalisme havia fet, des del segle xvirr, de tota mena d'institucions i principis socials, el corporativisme havia estat defensat per persones d'origens molt diversos: Sismondi, per exemple; els primers socialistes; l'escola social-catòlica des de Mun fins ara. També era corporativisme la transformació del sindicalisme revolucionari en quelcom de constructiu que Duguit havia proposat; també ho podíem trobar entre els «guildistes» anglesos (Prefaci a Severino Aznar, 1946, p. xi-xii).

Severino Aznar fou un dels ideòlegs del corpotativisme catolic més importants a l'Estat espanyol (fet palesat a I'excellent llibre de J. J. Castillo sobre els pagesos castellans, base social ferma d'aquest moviment). No solament citava Ketteler i Vogelsang, de Manning i Decurtins, Toniolo, Hitze i Lorin, sinó també el prefaci a la segona edició de La division du travail social de Durkheim: «Toda una escuela sociológica y positivista científica que tiene admiradores en todo el mundo culto ba llegado a las mismas con. clusiones que desde hace medio siglo están difundiendo los reformadores sociales católicos. Durkbeim, que no tiene ninguna religión positiva, y que es boy el mayor prestigio sociologico de Francia, llegó a las mismas conclusiones que Hitze, sacerdote, uno de los más ilustres campeones del régimen corporativo en Alemania; Duguit, que siente por el catolicismo una bostilidad siniestra de bugonote, coincide con aquel católico excelso que, para mala ventura del catolicismo social, emigró ba poco de la vida, con Henri Lorins (op cit, 1946, p. 214).

Va haver-hi influència dels alemanys Adam Heintich Müller, Franz von Baader, Ketteler, Hitze; dels austríacs Vogelsang, Seipel; també, però, de Durkheim i Duguit, que fou introduït a la Península Ibèrica per A. Posada (que no era pas catòlic si no m'equivoco) que tradú i presentà Lo transformación del estado (1909). Dues idees de Duguit van ser moit profitoses per a la ideologia corporativista: la concepció de la propietat com a «funció social» (que hom pot trobar també a la Constitució de l'Estat 
espanyol de 1978); la idea que «la lluita de classes podia ser calmada mitjançant l'establiment de reglaments contractuals que determinessin les relacions entre les classes", i d'aquesta manera l'Estat, donant el marc legal de la negociació collectiva, podia ajudar a fer desaparèixer l'amenaça del sindicalisme revolucionari, d'acció directa (la Carta d'Amiens és de 1907). Aquests punts de vista eren més útils, per tal d'enfrontar-se a un sindicalisme revolucionari basat en idees tan perilloses com que «la propietat és robar» $i$ en el principi d'acció directa, que no pas la insistència en el dret de propietat absolut (de dret romà o de dret «natural», tant se val) i la posició liberal extremista contrària a les coalicions de treballadors.

Els catòlics espanyols haurien volgut un corporativisme natural i espontani; després d'eliminar tants enemics de classe i de prohibir els sindicats obrers ben atrelats (com la CNT i la UGT) i funs i tot de deixar a la penombra les organitzacions empresarials, no tenien cap dret a pensar que el sistema fodria funcionar sense repressió. El corporativisme estatal va matar la base social d'un corporativisme espontani.

La història de la negociació collectiva després de 1958 mostra aquesta mancança de corporativisme social, fins $i$ tot al nivell més baix de les empreses i fàbriques. La Ilei de contractes collectius va ser part d'una colla de mesures preses entre 1958 i 1960, en part per consell de l'OECE (després OECD) i el Banc Mundial, adreçades a disminuir l'intervencionisme estatal a l'economia. Hom podia trobar una base ideològica per a la contractació collectiva al mateix pensament corporativista; també va ser vista, però, com una manera de lligar salaris i augments de productivitat.

Després del pla d'estabilització del 1959, l'economia va créixer molt i gairebé sense pauses fins al 1975. Va haver-hi moviments enormes de treballadors entre sectors (és l'època de falsos augments de productivitat a l'agticultura, estudiats per Naredo), amb emigració massiva cap a les cintats i cap a Europa. El Govern volia que els convenis collectius se signessin de manera descentralitzada, conservant facultats de prohibir-ne la seva vigència pel procediment d'homologació (que ara ja no existeix). El contracte podia ser tornat a la taula de negociació si implicava augments de salaris que semblessin inflacionaris. Les negociacions es farien dins dels sindicats verticals, entre eis tepresentants de treballadors i d'empresaris.

El naixement i el creixement de les Comissions Obreres a partir de la negociació collectiva han estat explicats sovint. La qüestió era d'aconseguir representants genuïns a les negociacions, concretament al Jurado de Empresa (una mena de comitè de treballadors), part de l'estructura sindical offial, que negociava per als treballadors (Amsden, 1971). El procediment d'assemblees massives, que consideraven propostes i elegien delegats temporals per negociar el conveni, es va desenvolupar espontàniament -aquests 
delegats a vegades eren membres del Jurado de Empresa i a vegades no. Alguns ernpresaris van acceptar fins i tot públicament aquest sistema paralegal, ja que podien fer acords amb representants tealment responsables. ${ }^{\dagger}$

La negociació collectiva a finals dels anys $1960 \mathrm{i}$ inicis dels anys 1970 es va fer sovint per acció directa $i$ amb intervenció d'assemblees massives de treballadors. Les causes eren la feblesa dels sindicats oficials, menyspreats malgrat ésser utilitzats com a tefugi legal pels treballadors, i també la dificultat de coordinació. Al Govern no li agradava gens el que succeia, però els convenis collectius eren vistos com un instrument necessari per a lligar augments de salaris $\mathrm{i}$ augments de productivitat.

Les coses haurien pogut set diferents. Per exemple, el vell sistema de reglamentació central hauria pogut contintar, amb generosos increments en aquests anys de creixement econòmic, les causes del qual eren exteriors, independents del grau d'intervencionisme estatal. El fet és, però, que es va imposar un sistema de negociació collectiva descentralitzat. ${ }^{2}$

Ei Govern insistia en la necessitat de convenis collectius fins i tot en l'agricultura latifundista. Calia que els funcionaris donessin contínuament explicacions a Madrid sobre convenis collectius fets a cada poble. Als pobles més militants (que després han elegit batlles de partits a l'esquerra del partit comunista) els treballadors no participaven en les eleccions dels «sindicats verticals»; d'altra banda, als anys 1960 encara no gosaven de fer assemblees ni elegir delegats extralegals, ja que la repressió era més forta que a les ciutats. Per tant, no podia haver-hi negociacions de convenis. Aquí tenim un cas de manca absoluta d'acords corporatius, fins i tot en aquest nivell més baix, a causa precisament de la introducció forçada del «corporativisme estatal».

Encara que la negociació collectiva podia ser defensada des de premisses clàssiques del pensament corporativista, la ideologia que es va emprar va ser cada cop més la que deriva d'anàlisis econòmiques. ${ }^{3}$ Podia haver-hi

1. La coordinació entre els representants treballadors de diverses empreses i lacalitats exa iHegal. A més, dins de Comissions Obreres van haver-hi desacords polítics. Poc a poc el Partit Comunista va anar agafant la direcció i a començament dels anys setanta els líders comunistes de Comissions Obteres van ser jutjats a Madrid (precisament el dia de desembre de 1973 que ETA va matar l'almirall Carrero Blanco) i enviats a la presó, d'on van sortir després de la mort del general Franco, al no. vetrobre de 1975.

2. Una altra especulació retrospectiva és aquesta: si els vells líders de la CNT a l'exili, en comptes de capficat-se en un sectatisme antisindicalista, haguessin posat el nom a disposició de les «comissions obreres» espontànies que naixien als inicis dels anys seixanta, dissolent la seva otganització residual, potser el vell sindicalisme revolucionari ibèric hautia trobat un lloc de tetrobament.

3. Les politiques de rendes no fan apeltació a nocions de justícia distributiva 
ja un nou corporativisme explícitament basat en la primacia de l'economia, com a l'Anglaterta de Harold Wilson o a l'Alemanya occidental de la "gran coalicio» de 1967 i de l'«acció concertada». Ara bé: era impossible d'establir un acord corporatiu central perquè no hi havia interlocutors veritables, especialment del costat dels treballadors. Els que podia haver-hi eren clandestins, eren a la presó, etc. Una política de rendes signada dins del Sindicat Vertical hauria fet riure tothom. Si l'estructura de corporativisme estatal era incapaç d'agombolar treballadors i empresaris a les fàbriques, molt menys podia fer servei per a un acord genetal sobre salaris. Per tant, ''Estat va haver d'intervenir amb l'arbitratge obligatori 1 també alguns anys amb decrets de congelació de salaris reals. L'últim d'aquests decrets, gairebé simultani a la mort del general Franco, no fou gens respectat.

Uns òrgans teòricament representatius, els dirjgents dels quals són nomenats pel Govern, no tindran capacitat per a establir acords ferms. Charles Anderson (1970) va emfasitzar l'amplària del debat econòmic a l'Estat espanyol als anys seixanta. No va insistir gens, pero, que un límit del «pluralisme autoritari» franquista era la impossibilitat d'un acord corporatiu central amb organitzacions obreres. La qüestió no era semblant a la manca de voluntat dels dirigents sindicals francesos de participar en pactes socials; a França no hi havia aquesta manca de representació.

En conclusió, la qüestió de si la classe obtera acceptaria una política de rendes basada en directrius macroeconòmiques no podia ser aclarida fins després de la mort de Franco, perquè els treballadors no tenien representants en situació de donar resposta oberta. ${ }^{4}$

\section{CORPORATIVISME: UNA PARAULA CONFLICTIVA}

Espanya (i Portugal, encara que Portugal és diferent, amb el seu ferm partit comunista "pro-soviètic») va canviat, a meitat dels anys 1970, d'un sistema polític corporativista a un sistema pluralista, parlamentari, precisament als anys en què en d'altres països europeus començava un debat

\footnotetext{
i commutativa, ni al decorum dels diversos grups socials, sinó a arguments econòmics, tnés idonis per tal d'arribar a un consensus social. El vocabulari aristotelic es continua emprant (un salari digne, per exemple, on la dignitat depen de l'estament social), però ha estat complementat pet un vocabulari econòmic.

4. Si a Polònia el Govern aconseguís d’aillar els radicals (que té a la presó) potser podria arribar a un acord sobre salaris i política econòmica entre Solidarnosc i la burocràcia del partit i de l'exètcit (que fan d'empresaris). El plutalisme és certament limitat; és gairebé suficient, peró, per assolir aquesta mena d'acord.
} 
científic sobre «neocorporativisme». D'una situació en la qual hi havia una Cambra corporativa i no hi havia partits polítics (o solament n'hi havia un), es va passat a una situació amb partits polítics que competien els uns amb eis altres en eleccions parlamentàries. De l'associació obligatòtia en cotporacions professionals (sindicats verticals, era el seu nom a Espanya) es va passar a una situació de llibertat d'associació i participació en els diversos sindicats de treballadors i organitzacions empresarials. Abans de 1973 no m'havia passat pel cap que el "vell» $\mathrm{i}$ el «nou» corporativisme tenien prou característiques comunes per portar el mateix nom. Em va obrir els ulls, The New Inflation d'Aubrey Jones, malgrat que la paraula "corporativisme» no hi sutt pas. Antic ministre conservador (de la tendència que en dinen wet, com el mateix Heath), Aubrey Jones havia estat nomenat per Wilson per dirigir el Prices and Incomes Board, un organisme consultiu la tasca del qual eta jutjar si els acords sobre salaris dels convenis collectius eren inflacionaris i també determinar criteris sobte diferències de salaris. Arribava a la conclusió que hi mancaven criteris econòmics per a establir si els augments de salaris determinats per la lliure i descentralitzada negociació collectiva tradicional a Gran Bretanya eren o no eren excessius, i propo. sava la creació d'una Cambra corporativa (sense fer-ne servir el nom) on els representants d'ambdues bandes poguessin decidir una política de rendes.

El supòsit (durkheimià) implícit era que hi hauria un grau suficient de consensus, potser perquè els actors socials entendrien l'imperatiu de l'equilibri de pagaments exteriors. Era un supòsit optimista, ja que fins i tot hi havia gent disposada a fer una anàlisi de classe del balanç de pagaments (per què no?). Semblava, doncs, que la inexistència d'un criteri teòricoeconònaic capaç de jutjar la distribució de l'ingrés podia portar d'una banda a l'estratègia sindicalista proposada, per exemple, per Glyn i Sutcliffe (1971), però, també, paradoxalment, a un revival corporativista.

Encara que m'adonava de l'ofensiva del neoliberalisme econòmic, fins al triomf de Thatcher no creia que la fe en el metcat tingués una resurrecció tan espectacular (i paradoxal, en coincidir amb la nova consciència que el mercat és incapaç per assignar recursos exhauribles entre generacions.

A més, abans d'arribar a la conclusió que el neocorporativisme explícit eta la nova ideologia capitalista $i$ socialdemòcrata (em va sorprendre la proposta d'una tercera Cambra, corporativa, a Gtan Bretanya) calia haver discutit fins a quin punt el keynesianisme podia encata fer servei com a suport iđeològic de pràctiques corporativistes informals. Per exemple, la noció de Kaldor segons la qual el creixement depèn dels guanys (estalviats) que són la font de la inversió i que per tant una taxa determinada de creixement desitjat depèn d'una determinada taxa de guanys (suposant, és clar, una relació incremental capital/producte donada), ha estat un suport 
dels acords corporatius, sense necessitat, per tant, d'ideologia "durkheimiana». L'eficàcia d'aquest argument potser depèn, a hores d'ara, especialment del prestigi intellectual que la crítica ecològica de les teoties econòmiques del creixement pugui assolir.

El subtítol del llibre d'Aubrey Jones era «La política dels preus i dels ingressos». Des del punt de vista del politòleg, el corpotativisme és vist especialment com un sistema extraparlamentari de representació i d'intermediació d'interessos organitzats. En el «vell» corpotativisme, el mateix Parlament seria substituilt per una Cambra corporativa, mentre que en el "nou» corporativisme una de les qüestions més analitzades ha estat Ies relacions entre el sistema de representació política a través dels partits i el sistema d'interessos organitzats. Per a un economista, corporativisme vol dir, sobretor, determinació fora del mercat de pretus i ingressos. ${ }^{5}$

Si extraparlamentari és una paraula grollera en un tègim parlamentari, «extramercat» és gairebé un insult en una economia de metcat generalitzat. Admetre que els preus i els ingressos són qüestions polítiques pot ésser moit inconvenient, car la teoria econòmica s'ha fet servir (tant la microeconomia ortodoxa com la macroeconomia keynesiana de curt i llarg termini -encara que no pas l'economia marxiana o sraffiana, o l'economia ecològica de Georgescu-Roegen) per legitimar la distribució desigual de l'ingrés. Per aquestes raons, ens trobem que el corporativisme, amb les seves connotacions extraparlamentàries i extramercantils, no és la ideologia explícita de gairebé ningú. És una realitat sense ideologia.

La paraula «socialisme» ha servat sempre una certa connotació favorable a la igualtat, mentre que la paraula «corporativisme» precisament denota un sistema que estructura permanentment la desigualtat i la ideologia que defensa aquest sistema. El rebuig de la paraula «corporativisme» pels practicants socialdemòcrates del neocorporativisme és símptoma de pro blemes de legititnació d'aquestes pràctiques."

Els conceptes que serveixen per a analitzar la política són, ells matei-

5. Potser l'únic cas d'una mena de Cambra corporativa en paisos amb règims parlamentaris ha estat el Consell Econòmic i Social als Països Baixos. Hi ha dificultats a reconciliar l'existència d'una Cambra corporativa amb la teoria d'una demo cràcia pluralista. Als autors austríacs, els agrada dir que la Comissió Paritària no té cap local a Viena, no té telèfon.

6. Per interpretar la transició política que s'apropava a l'Estat espanyol he proposat la idea d'un neocorporativisme amb certa freqüència, L'octubre de 1975, convidat pel Cercle d'Economia a una de les reunions a la Costa Brava, on gairebé tothom defensava un pacte social, vaig dir que d'això se'n podia dir corporativisme, la qual cosa em va fer guanyar una forta renyina de Ferrer Salat i cap suport de ningú. Un diari de Madrid («Informaciones») se'n va fer resso. A "Cuadernos de Ruedo Ibericos vaig publicat un article arran del Pacte de la Moncloa. Parlava de necos. 
xos, components de la realitat política. L'èxit en la introducció d'un terme polític depèn de l'acceptació general o d'un sector social, i pot influir sobre la realitat política. La terminologia política és ella mateixa una qüestió de distribució de foder (Connolly, 1974, p. 80). La distinció entre termes descriptius (o analítics) i termes normatius, no funciona gens bé en el llenguatge de la ciència política. La lluita política és també una lluita sobre conceptes i paraules, $i$ «corporativisme» n'és un bell exemple.

La paraula «cotporativisme» s'ha utilitzat en sentits diferents, separats pels adjectius «autoritari», «estatal», «vell» per un, i «liberal», «social», «nou» per l'altre. Aquesta diferència es pot trobar ja a Maïnolesco (com Schmitter va assenyalar al seu brillant article de 1974), i també a la tradició intellectual socialdernòcrata (per exemple a les tesis d'Otto Bauer en 1933 i 1934, sense que Bauer i Maïnolesco s'esmentin múttrament). Aquests dos tipus de corporativisme són també diferents perquè el «vell» corpotativisme era merament una doctrina, una ideologia; el «nou» corporativisme és una realitat que busca una ideologia que no sigui explicitarment corpotativista.

El cas espanyol d'ençà de 1977 és exemple de corporativisme liberal, parlamentari -acords tripartits sobre salatis negociats fora del Parlament i del mercat tot preservant la desigualtat social-, i tanmateix cap dels seus polítics, líders obrers o líders empresarials no confessa ser partidari d'una doctrina corporativa. Linz i Maravall han estat informats de la discussió internacional sobre neocorporativisme; cap dels dos (1981, 1982), però, no ha fet servir aquest concepte per a analitzar l'estructura político-econòmica emergent, ni l'han rebutjada ni l'han discutida. Werner Lang (1981) preveia erròniament que no hi hauria més pactes socials, però va discutir el Pacte de la Moncloa dins el debat internacional sobre neocorporativisme.

A la pràctica, hi ha episodis periòdics de «soroll d'espases» amb efectes polítics. A més, la Constitució de 1978 dóna a l'exèrcit un paper (a l'article 8 , d'interpretació ambigua) poc freqüent en d'altres päsos occidentals parlamentaris. L'amenaça d'aquest òrgan de l'Estat s'ha fet sentir (segons les manifestacions dels actors) a les taules de negociació de gairebé tots els «pactes socials» des de 1977. Una definició del nou règim espanyol d'ençà 1977 i almenys fins 1983 setia la de corporativisme liberal parlamentari

porativisme, encata que no havia Ilegit Schmitter, Lehmbruch, Panitch o Winkler. Una mica menys d'indignació i una mica més de coneixement de la discussió internacional I'hauria millorat. Entre 1978 i 1983 he publicat altres articles a diaris i revistes com «Bicicleta», «Solidaridad Obrera» $\mathrm{i}$ «Egin». EI juny de 1981 vaig enviar un article a «El País», publicat el desembre de 1981, preguntant con era que s'havia importat la terminologia neocorporativista («concertació») sense importar simultàniament el debat: potset era massa fort? L'article no va tenir cap tesposta. 
amb forta presència militar, no merament com a «corporació» amb interessos professionals propis, sinó amb un projecte polític propi pel que fa a la unitat de l'Estat espanyol enfront dels separatismes nacionalistes.

Encara que «corporativisme» fos una descripció adequada, amb valor analític, és de totes maneres un concepte massa «fort»: la seva utilització és una qüestió política. Els termes «estat corporatiu», «economia corporâtiva» $i$, en general, «corporativisme» han estat utilitzats més sovint com a insults que com a elogis en el debat internacional des de mitjans de la dècada dels setanta. En alguns casos, però, el terme ha estat utilitzat elogiosament, per exemple teferint-se als paisos ibèricollatins (Wiarda, Pike, 1974), encara que en un d'aquests pä̈sos (si podem classificar el Perú com a ibèrico-llatí) Julio Cotler va criticat el règim militar, des de 1971, explicant que tractaven de construir un estat corporatiu, una crítica tan eficaç que fou deportat. Un exemple d'utilització elogiosa, a l'«International Herald Tribune» (de 21 de juny de 1977), deia que les socialdemocràcies alemanya i britànica caminaven cap a la creació d'un nou tipus d'estat corporatiu, basat en la collaboració tripartita de Govern, sindicats i empresaris. Segurament un diari d'arrels europees no hauria utilitzat aquest terme d'una manera tan innocent. Ês evident que les socialdemocràcies alemanya i britànica no volien substituit els Parlaments per Cambres corporatives. Potser la collaboració tripartita per tal d'arribat a acords (extraparlamentaris $i$ extramercat) sobre salaris i d'altres matèries de política econòmica es podria descriure no pas com un nou sistema corporatiu sinó com una estructura corporativa dins del sistema político-econòmic general (seguint Panitch, Kastendiek).

En un sistema corporativista, o quan hi ha estructures corporativistes, la defensa organitzada dels interessos (que fa possible parlat del corporativisme dels metges, o dels PNN, o dels obrers de tal o tal altra fàbrica) desemboca en acords generals, normalment amb intervenció de l'estat.? Així, el Pacte de la Moncloa de 1977 representà el primer moment del neocorporativisme hispànic. No va ser signat (a diferència dels pactes socials posteriors) per representants de sindicats i d'organitzacions empresarials

7. El líder de la UGT, Nicolás Redonda, explicava a «EI País», l'll de juny de 1983, que els sindicats podien optar per una d'aquestes tres vies: actuat de manera que ajudessin a l'arribada d'una solució política neoliberal, amb contingut antisindical clar; decidir-se per una política de grans acords, amb sactilicis i contrapartides equilibrades; la negociació lliure, descentralitzada per sectors, que inevitablement donaria lloc a pràctiques ecorporativistes». Veien aquí una clara defensa del corporativisme, reservant -a la moda italiana i francesam la paraula per a actuacions que a la Iiteratura academica no tenen un nom establert. El que en un Hoc s'anomena free collective bargaining amb connotació en general positiva, potser se'n diu Betrieb-Egoismus en un altre Iloc, com a insult. 
perquè la CEOE encara no estava consolidada i perquè als primers governs postfranquistes hi havia presència molt directa dels gtans empresaris; d'altra banda, els líders de Comissions Obreres i d'UG'T eren membres del Parlament, i quan el Pacte de la Moncloa signat fora del Parlament es va debatre al Parlament amb celeritat meteòrica, cap dels dos no va dir res en contra. Bona part dels treballadors estava en contra ( $O$ potser simultàniament en contra i a favor, Pérez Díaz, 1979), la qual cosa explica l'actitud pública poc entusiasta dels líders de la UGT. La campanya contra el pacte social dels partits d'esquerra abans de les eleccions del juny de 1977 i la tradició de Comissions Obreres, de negociació collectiva descentralitzada, van aconseliar de suplementar l'acord corporatiu sobre normes salarials amb un acord entre partits polítics, fortanent legitimats per l'alta taxa de participació a les eleccions parlamentàries. Als pactes posteriors s'ha separat l'acord entre interessos organitzats (sovint amb participació també del Govern) de les actuacions del sistema de partits, ja que en una economia de mercat el Parlament no té perquè intervenir en la negociació de sadaris $\mathrm{i}$ condicions de treball.

En un sistema de corporativisme estatal era impossible de fet acords corporatius genuïns. A l'Estat espanyol actual, per contra, malgrat la feble implantació dels sindicats (mesurada pel nombre d'afliats) hi ha interme. diaris vàlids. El grau de compliment dels pactes socials fets d'ençà 1977 és molt alt. Això no vol dir que els treballadors estiguin d'acord. Jo parlaria més aviat d'una barreja d'acord i de desacord característica de la «consciència dual» dels treballadors en paìsos com els nostres o més pobres.

Quines són, tanmateix, les bases ideològiques d'aquests acords? Mal. grat les freqüents apellacions a la necessitat de «consolidar la democràcia», dificilment es pot dir que la ideologia darrera dels pactes socials és la d'evitar un cop d'estat pels militars. Això no serveix com a ideologia o en tot cas com a única ideologia (ni aquí, ni a Brasil, ni a Argentina). Ens hem de preguntar, doncs, ¿com va ser que els sindicats van agafar una orientació macroeconòmica els anys 1975-1977 i encara no l'han abandonada? ¿Es probable que aquesta orientació resisteixi un periode perllongat de manca de creixement? Si la macroeconomia tant de curt com de llarg terme és cada cop tnés qüestionada, ¿podem esperar una resurrecció de doctrines corporativistes basades en l'harmonia social més que en arguments econimics? ¿Les doctrines d'harmonia social són compatibles amb les tradicions intellectuals de sindicats que es diuen socialistes $i$ comunistes, $i$ sobretot amb la imatge de la societat (dividida en classes) que la majoria dels treballadors tenen aquí? ¿O potser la nova ideologia dels acords corporatius com a scambio politico i rational cboice artelarà entre els actors socials? 


\section{LA LEGITIMACIÓ DE LA DESIGUALTAT PERMANENT}

Des de les revolucions liberals s'ha pensat que la representació política calia que fos territorial i no pas corporativa. Els representants ho eren de tots els ciutadans de la circumscripció que els havia elegit, i no pas de determinats grups. Mentre Edmund Burke s'escandalitzava de la composició del Tiers État de ''Assemblea Nacional dins del qual no es podia trobar ni el inés petit senyal "del que anomenem interès natural de la propietat agtària del país» $(1790$, p. 132), Thomas Paine elogiava la moció de l'Abbé Sièyes per la qual «el Tiets État o Communs es van declarar els representants de la Nació, i per la qual els dos ordes no podien ser considerats res més que diputats de corporacions, i podien tenir solament una veu deliberadora quan es reunien amb eis representants nacionals» (1791, pàgina 127).

La teoria política liberal anomena «grups de pressió» els interessos organitzats i hom lamenta el lobbying que poden fer mitant d'influit els parlamentaris. ${ }^{8} \mathrm{El}$ fonament d'un sistema neocorporativista és que els grups d'interessos organitzats deixen de tenir aquest caràcter sospitós de «grups de pressió», per tornar-se, en el vocabulari més lític, fins i tot sozialpartners, que és com les organitzacions empresarials i sindicals s'autodenominen a Austria.

Una diferència bàsica entre el vell i el nou corporativisme és l'autenticitat de representació dels interessos socials. Una altra diferència bàsica és que el nou corporativisme té com a ideologia no pas l'harmonia social per se sinó la necessitat d'harmonia per a aconseguir el creixement econòmic, dins d'un marc teòric de macroeconomia keynesiana tant de curt com de llarg termini.

Si la teoria del creixement econòmic perd credibilitat els anys propers, aleshores l'argument de restringir els augments salarials per tal de fer puijar la inversió no convencerà gaire. Es podria proposar una economia sense creixement dins d'una societat estamental; aquesta mena de corporativisme, però, fóra molt difícil d'empassar per la socialdemocràcia, ja

8. Una troballa de la transició política a J'Estat espanyol ha estat el terne poder fáctic. Ha estat poc freqüent anomenar poder fàctic a les Organitzacions Empresarials, a les Organitzacions Agtàties, als Sindicats, perquè han tingut menys poder que I'Església, l'Exèrcit i la Banca i perquè el seu poder sembia més compatible amb el sistema liberal. Si hom no negacia els preus agraris, per exemple, hi ha el perill que tes Organitzacions Agràries negociin amb acció directa, traient tractors a les catreteres. Amb la Banca les coses són més subtils: si hom no negocia els augments de coeficient de liquiditat, què podria succeir? Quina pressió podria fer directament aquest grup de pressió? 
que hauria de basar-se en doctrines d'harmonia social i en la collaboració de grups de ciutadans desiguals arnb ufuncions socials» permanentment diferenciades més que no pas en les doctrines econòmiques que encara es fan servir." Una altra possibilitat fóta de fer acords de moderació salarial i de desigualtat permanent a canvi d'una veu més gran per a les organitzacions obreres en l'administració de l'economia. És una idea antiga, que dins de la tradició socialdemòcrata s'anomena "d̉emocràcia econòmica» o «democràcia industrial». Aquí té interès de recordar les propostes d'Otto Bauer en 1933 i 1934, quan va explicar que «democràcia econòmica» i «democtàcia industrial» eren termes sinònims de «corporativisme auto regulat». ${ }^{.0}$

Otto Bauer va escriure que la lluita de classes a Austria en aquell moment passava per la interpretació de la Quadragessimo Anno. Encara que el papa fes elogis del feixisme, hi havia una diferència fonamental entre el corporativisme feixista (amb funcionaris nomenats pel Govern o el partit, sense llibertat d'associació $i$ sense dret de vaga, sense partits polítics i sense Parlament) i el que ara en diríem «corporativisme liberal», que Bauer va anomenar berufsändische Selbsverwaltung (autoadministració o autoregulació corporativa), un concepte similar al de «capitalisme organitzat» (de Hilferding) o al de «democràcia industrial» o «econòmica». Els capitalistes i els treballadors collaboratien, mitjançant llurs organitzacions, en noves institucions similars a les que havien nascut de la negociació collectiva (Tarifgemeinscbatien). Tractarien moltes altres qüestions a més de salaris i condicions de treball. Per exemple, podrien determinar producció i preus, per a cada sector econòmic.

Bauer va dir que el «corporativisme estatal» (que ell anomenava Kor porationensystem italià) mataria el "corporativisme social». Esperava que els catòlics hi estiguessin d'acord, pel principi de subsidiarietat de l'Estat.

9. Al corporativisme antic no ji calia una ideologia de cteixement. Un exemple és el salazarisme, almenys fins ben entrada la dècada dels seixanta, (Manuel de Lucena, $A$ evoluçao do sistema corporativo portugués. O Salazarismo, Perspectivas e Realidades, Lisboa, 1976).

10. Bauer, articles a Arbeiter-Zeitung, 1933, a Werkausgabe, vol. 7, pp. 496-517, i «Klassenkampf und Ständeverfassung», Der Kampf, gener 1934, Werkausgabe, vol. 9, p. 341. Hi ha una explicació detallada, en anglès, de les propostes d'Otto Bauer a Chaxles A. Gulick, Austria. From Habsburg to Hitler (University of California Press, Berkeley, 1948, vol. II, pp. 1222-1229) on Berutständiscbe Selbsverwaltung és traduit per occupational-estates self-management, reservant la parauia «corporativisme» per al Italian corporative system. Això és una mica tidiful perquè en alemany es pot jugar amb la paraula getmànica i la paraula llatina; en angles, però, la paraula germànica hi manca en aquest cas. Occupational-estates self-management vol dir, en bon anglès, corporatist self-manogement. 
No va discutir la qüestió Parlament vetsus Cambra corporativa. La seva anàlisi inclou un sumari excellent dels corrents de pensament corporativista, fins i tot amb un comentari sobre el sindicalisme revolucionari de Pelloutier i Grifoulhes. Es basa en una visió històrica del desenvolupament del capitalisme monopolista, la qual cosa li permet de dir que ja no hi pot haver liberais econòmics genuïns. A Austria, després de la primera guetra, no sols els treballadors sinó també els industrials i els banquers havien perdut poder en benefici d'aristòcrates, buròcrates i generals; entre treballadors i capitalistes encara hi havia, però, una situació de Gleichgewicht, d'equilibri -això era ja a la tardor de 1933. Així, doncs, l'autoadministració corporativa, sinònim de «democràcia econòmica» o «industrial», no era pas vista de cap maneta com un camí cap al socia. lisme, que les circumstàncies feien inviable. En aquell moment, en comptes d'emprar els vells mots de capitalisme organitzat, democràcia industrial o econòmica, s'estimava més - per defensar la socialdemocràcia davant l'imminent atac, armat, dels catolics- el mot de corporativisme, com si fes l'ullet al papa de Roma. La paraula «corporativisme» denota un sistema permanent de desigualtat. Per tant, la socialdemocràcia s'estima més paraules com «democràcia econòmica» $i$ «concertació» per legitimar les pràctiques neocorporativistes. E1 1933, Bauer va fer una tria terminològica contràría.

De vegades es vol «explicar» l'actitud dels sindicats que fan pactes socials amb teories de rational cboice (seguint Peter Blau, Brian Berry) o, en termes semblants, d'scambio politico (seguint a Pizzorno). Colin Crouch (1982) raona des de la premissa que el que interessa els treballadors és tenir sous més alts i millors condicions de feina dins d'un marc capitalis. ta. Els sindicats poden estar disposats a intetcanviar restriccions salarials per una influència més gran sobre l'assignació dels fons d'inversió, en l'administració de les fàbriques. Renuncien precisament a la consecució de sous més alts a canvi de dosis més grans de «democràcia industrial» o de «democràcia econòmica». L'elecció és racional, perquè fan un intercanvi d'unes dosis d'objectius per unes dosis d'altres millores.

El que els teòrics del rational choice $i$ apologistes dels pactes socials es pensen que expliquen és la renúncia (no pas a hipotètics objectius revolucionatis, que hom suposa que els treballadors no tenen) als objectius economicistes. Els treballadors demanaven a les fàbriques salaris més alts i no ho feien pas per portar els guanys a zero ni enfonsar el capitalisme. Tampoc no ho feien per ajudar el capitalisme. Ara bé, els acords corporatius introdueixen un objectiu nou: ajudar el capitalisme. El procediment determina els objectius. No hi ha una elecció racional entre objectius diversos, combinant una mica de I'un i una mica de l'altre; el que hi ha 
hagut, amb 12 introducció d'acords corporatius, és un canvi d'objectius als sindicats, que abans no s'havien pas proposat d'ajudar a la consolidació del capitalisme. Caldria explicat aquest canvi, cosa que els teòrics del rational choice no fan, ja que aquesta paròdia de microeconomia no entra en l'anàlisi històrica dels valors i de les preferències. Observa «preferències tevelades» i les "explica» tautològicament.

Els sindicats tenen objectius contradictoris, incompatibles els uns amb els altres, i no hi ha trade-offs basats en elecció racional sinó movinent històric cap endavant, cap endarrera, de costat. La coherència en les eleccions és un supòsit de la teoria econòmica respecte als individus hipotètics de la microeconomia, no és pas una realitat pels actors socials, cadascun dels quals pot tenir una diversitat d'objectius simultanis irreduïbles a una sola dimensió. Si abandonem la unidimensionalitat utilitarista, és ben clar que no solament els sindicats sinó els individus poden ser inco herents en les seves eleccions.

El corporativisme cristià, el corporativisme durkheimià, el que proposava Otto Bauer, el corporativisme jeynesià-socialdemòcrata i el corporativisme del scambio político i rational cboice tenen en comú la desconfiança envers els resuitats del mercat i l'objectiu d'harmonia social.

Hi ha diverses maneres d'oposaz-se al corporativisme. Una és la de. núncia del corporativisme com un sistema estructurat de desigualtat, que el fa condemnable des de posicions ideològiques igualitaristes. Per això, els que, fent servir el nom de "socialistes" no poden pas dir que estan a favor de la desigualtat permanent, s'empipen per l'ús de la paraula corporativisme i fan servir eufemismes. Ara bé, es pot condemnar el corporativisme dels pactes socials també des de la dreta, tal com succeí a An. glaterra als anys anteriots al triomf de Thatcher (dins del mateix partit conservador hom podia trobar postures corporativistes, com les d'Aubrey Jones, 1973, i anticorporativistes, Keith Joseph, 1976).

Un dels primers atacs antisindicals i neoliberals contra el neocorpotativisme es pot trobar, coherentment, a Hayek (1960, p. 282.283). Diu així:

«Ais països en els quals hi ha hagut tendències inflacionàries des de fa algun temps, podem observar peticions cada cop més freqüents d'una "política salarial general"... Això no és res més que el tesultat inevitable de les actuacions actuals dels sindicats, que estan dirigides pel desig que els salaris siguin determinats per algun concepte de "justícia" en comptes de ser determinats per les forces del mercat... Quan ja no podem refrar-nos de la determinació impersonal dels sałaris pels mercats, l'única manera de conservar un sistema econòmic viable és que els salaris siguin determinats de manera autoritària pel Govern. Aquesta determinació ha 
d'ésser necessàriament arbitrària, ja que no hi ha estàndards objectius de justícia que puguin ser aplicats. El mateíx que qualsevol altre preu, les taxes de salaris que són compatibles amb una oportunitat oberta per a tothom de trobar ocupació no es corresponen amb cap mèrit que hom pugui jutjar ni amb cap estàndard de justícia independent, sinó que depenen de condicions que fugen del control de tothom... Sota aquest sistema, els sindicats podran triar únicament entre convertir-se en instrument voluntari de la política del Govetn o desapatèixer totalment. La primera alternativa és més probable, ja que permetrà que la burocràcia sindical existent conservi la seva posició i una mica del seu poder petsonal. Pels treballadors, però, suposarà una subordinació completa al control d'un estat corporatiu... La posició actual dels sindicats no pot continuar, ja que els sindicats poden existir únicament en una economia de mercat i estan fent tot el que poden per destruir-la.»

No tots els austriacs tenen doncs tendències corporativistes! Els sindicats, pensa Hayek, són una interferència estranya a l'economia de mercat, on els individus fan transaccions. No són pas un producte històric, irremeiable, de la lluita de classes." La predicció que, als anys de plena ocupació, els sindicats podien posar en dificultats el sistema capitalista i que l'alternativa seria introduir pactes socials generals contra la negociació collectiva fàbrica per fàbrica fou moit encertada. ${ }^{12}$ Aquesta predicció, que un capitalisme de mercat amb sindicats forts i plena ocupació no pot funcionar $i$ té tendència a convertir-se en un capitalisme corporativista, ja l'havia feta Kalecki (1943). Kalecki eta contrati a l'abolició dels sindicats. Va predir la creació cíclica de desocupació per a mantenir els sindicats a ratlla. Kalecki (com Joan Robinson) creia, tanmateix, en la possibjlitat d'una teoria purament econòmica del creixement. Els keynesians d'esquerra (més kaleckians i marxistes que keynesians) mai no van plantejar-se la qüestió dels recursos exhauribles, i no ens poden servir, doncs, de guia científico-política.

Ara bé, suposem que la illusió del creixement fa figa. De quina maneta podran legitimar Ia desigualtat? ¿Un neocorporativisme més aviat

11. L'existència mateixa dels sindicats es pot explicar amb xeduccionisme individualista, com, per exemple, ha volgut fer Mancur Olson. La consciència de classe, els objectius collectius no hi juguen cap paper: a l'inrevés, individus racionals estudien els avantatges que traurien de la seva inscripció i la seva participació als sindicats; no hi ha actors socials, hi ha coalicions d'individus racionals.

12. El neoliberalisme va esperar que arribés Ia crisi: si, a Anglaterra, Thatcher pot estar contra una incomes policy havent introduït el desconcert més gtan a l'esquerra, dividida entre pattidaris i contraris d'un pacte social, és precisament perquè el mercat laboral funciona molt «millor» quan hi ha uns quants milions d'aturats. A l'Estat espanyol hi ha empresaris que pensen que ja no cal fer pactes socials. 
durkheimià que keynesià, sota gestió socialdemòcrata, que farà servir paraules com «concertació», «democràcia econòmica», potser fins i tot wharmonia social»? ¿Un renaixement del darwirisme social individualista, sota gestí política neoliberal? Si la legitimació manca, pot havet-hi violència oberta d'una banda i por i resignació de I'altra, dins cada Estat i internacionalment. En contra d'aquestes perspectives hom pot lluitar amb l'antiga arma de la ràbia dels pobres contra els rics, prou raonable, i també amb els instruments teòrics que l'economia ecològica ens dóna per apropar-nos a una «història del futur» factible i desitjable.

Una economia sense creixement o amb decreixement no exigeix pas, com una qüestió de lògica, una distribució més igualitària. L'ecologisme, que pot posar en qüestió les teories del creixement econòmic, no sempre és d'esquerra, perquè de vegades és «optimista» respecte al creixement (la diferència amb l'economia està a patlar del fiux d'energia i dels cicles de materials en comptes de parlar d'inversió i de producció, i no pas necessàriament en el grau d'«optimisme»), i perquè de vegades va del bracet amb el socialdarwinisme.

\section{LA CRITICA ECOLOGICA.}

\section{NEOCORPORATIVISME KEYNESIA_SOCIALDEMOCRATA}

Considerem una expressió com «la producció de petroli». El titme d'extracció de petroli és molt més ràpid que el ritme de la seva formació geològica. ¿Es pot traduir aquesta frase dient: «el ritme de producció de petroli és molt més ràpid que el seu ritme de formació»?

L'expressió «el PIB cteixerà un 1 per cent l'any vinent» és potser una expressió metafísica, malgrat que é: moit fàcil verificar en la Comptabilitat Nacional si les xifres deI PIB (en termes «reals», que vol dir, per als econormistes, descomptant hi la inflació dels preus) han pujat o han baixat. Aquestes xifres es calculen sumant els "valors afegits» per totes les empreses $\mathrm{i}$ activitats econòmiques, és a dir, els valors de les vendes menys els valors de les compres d'inputs. Ara bé, dins aquesta "producció», la destrucció ha estat adequadament valorada?

En els models de creixement econòmic, ¿quin contingut té una proposició com aquesta: «un augment de la inversió neta fa augmentar la producció»? Inversió Neta és definiła com a augment de la capacitat «productiva». Quan els macroeconomistes parlen de "producció» han decidit de donar uns pesos concrets als diversos ingredients d'aquesta barreja. ¿Els pteus dels recursos exhauribles destruïts estan «ben» posats? 
Quan es fa la correlació entte Inversió Neta (privada i estatal) i Augments de la Producció, s'observa, els últims anys, que augmenta la capacitat "productiva» (encara que potser més a poc a poc) i no augmenta gairebé gens la "producció». El llenguatge dels economistes permetria una proposició com aquesta: «l'estagnació de la producció to té per causa tant les deficiències de demanda efectiva com l'increment de la relació incremental capital/producte». Ara bé, dir que «l'estagnació de la producció té pet causa l'increment de la relació incremental capital/producte» és tautològic, ja que si la producció està estancada i l'estoc de capital augmenta (tot això mesurat amb l'atitmètica de la Comptabilitat Nacional), aleshores augmenta evidentment la relació incremental capital/producte. Per a no ser tautològica, la proposició hauria d'analitzar el contingut de la inversió i de la producció.

La microeconomia i també la macroeconomia es basen en l'individualisme metodològic, encara que pugui semblat que la macroeconomia, que tracta de les relacions entre les magnituds agregades de l'economia (el Producte Total, l'Ingrés Total, el Consum Total, l'Estalvi i la Inversió Totals), no ho faci. A la teoria macroeconòmica (es diu) li cal agafat l'agent individual com a típic o tepresentatiu dels aitres, i afirmar que la humanitat, en conjunt, és tan tacional com ell. «Per exemple, l'anàlisi de Ia inversió, de l'estalvi $\mathrm{i}$ de la preferència per la liquiditat que ocupa la major part de la Teoria General de Keynes adopta precisament aquesta forma. Abans d'explicar els salaris baixos per l'interès dels capitalistes, com a grup, perquè siguin baixos, cal demostrar que cada capitalista actua racionalment i d'una manera tal que, agregadament, produeix aquest efecte. Abans que els sindicats o els accionistes puguin ser considerats com a collectius, són analitzats com a coalicions d'individus, cadascun amb interès per complir les regles que els uneixen i per actuar conjuntament» (Hahn i Hollis, p. 3). Els moviments mactoeconòmics són, doncs, explicats com a resultat collectiu de les accions d'individus racionals. «Les raons pedagògiques per les quals l'economista pur comença amb l'anàlisi micro reflecteixen també aquest profundíssim compromís ontològic» (ibid.). Per exemple, preguntem-nos quina raó hi ha perquè els salaris no baixin gaire malgrat la desocupació. De seguida podem pensar en dues menes d'explicació possibles ben diferents. La primera diria que els sindicats aconsegueixen de mantenir els salaris encara que no són pas salaris d'«equilibri». Una altra explicació seria cetcar els fonaments individualistes, analitzant la conducta d'empreses i de treballadors; la literatura sobre «contractes implícits» (Okun, 1981; Tobin, 1983) explica que les empreses sovint conserven els seus treballadors, pagant sous alts, petquè en Ilogar-ne d'altres, tindrien costos d'entrenament, haurien de buscar el tipus idoni de treballador, etc. Es mira de posar fona- 
ments microeconòmics (basats en l'intercanvi) als fenòmens mactoeconòmics, com ara l'estabilitat dels salaris en època de crisi.

Keynes va considerar la inflexibilitat de salaris com una dada, sense recótrer a explicacions basades en l'acció racional d'individus ni en l'acció collectiva. Keynes mateix va mirar sovint, però, de posar bases individualistes a d'altres fenòmens macroeconòmics, per exemple, en discutir la fun" ció agregada de consum/estalvi, on el supòsit és que la persona tacional estalviarà una part més gran del seu ingrés en augmentar aquest. En canvi, estariem adoptant un «collectivisme metodològic» si expliquem la propen. sió a l'estalvi a la manera kaleckiana (la variable és la classe social) o si la relacionem amb el cicle de desenvolupament de la família i per tant amb l'estructura demogtàfica, o si incloem en l'explicació regles socials, com ara el sentit veblenià d'imitació dels consums dels rics.

La teoria del creixement econòmic que els economistes fan servir és gairebé sempre keynesiana, desenvolupada especialment a partir d'Harrod (1939). Hi va haver un economista (Ise, 1950, pp. 415-416) que va remarcar que la teotia keynesiana deixava de banda la qüestió de la disponibilitat de recursos naturals. Però la majoria d'economistes va pensar que hom podia convertir el keynesianisme en una teoria de creixement a llatg termini. Per exemple, Arthur Okun, al seu libre pòstum (1981), encara considerava que hi ha una «línia de tendència de prosperitat» (p. 272) comparant amb la qual podem quantificar les pèrdues en producció real que la crisi representa.

Es a dir, hi ha una hipotètica «línia de tendència de prosperitat» que ens indica que l'economia podria créixer, per exemple, el tres (o el quatre, o el cinc) per cent anual, o realment «el pare carabasser», perquè la xifra és quiromàntica, basada en la idea que si la inversió anual fos un cert percentatge del PIB, i si la relació Inversió/PIB fos més o menys estable, aleshores, si no manqués demanda efectiva, l'economia podria anat seguint la seva «línia de tendència».

Okun volia analitzar també si la pèrdua de producció en els anys de crisi, per sota de la «línia de tendència», reflecteix acuradament el cost «social» de la crisi, en el sentit que els economistes utilitzen la paraula «social», és a dir, si hi ha costos $\mathrm{i}$ beneficis no capturats pels valors de metcat. La llista de possibles correccions (p. 274) inclou el fet que «la producció més petita (que la possible) dels períodes de recessió i tecuperació fa que el desgast dels béns de capital existents i l'extracció de recursos naturals norenovables, com els productes de les indústries mineres, siguin més petits».

Una bona comptabilitat hautia de compensar els recursos naturals exhauribles que s'utilitzen en la producció amb partides d'«amortització» que fessin que la capacitat productiva no disminús. «Menjar-se» un pou de 
petroli s'assembla molt a «menjar-se» un tractor, descapitalitzant-se, si hom oblida restar una partida dels ingressos per a amortització. Ara bé, Okun, en discutir Ia correcció pertinent al valor «social» de la disminució de crei. xement de PIB en època de crisi que vindria d'una utilització més petita de recursos exhauribles, deia així: «Els comptes nacionals no tegistren cap deducció per l'esgotament de tecursos exhauribles, ja que el valor dels nous descobriments de recursos exhauribles tampoc no és valorat. El valor de les provisions per esgotament als comptes de resultats de les empreses suposa menys de la meitat d'un 1 per cent del PIB, la qual cosa suggereix que la correcció apropiada del cost social (de la crisi) a causa de l'esgotament més lent, és trivial» (p. 275).

Si algú no ho ha entès del tot, podria pensar en aquest exemple. Suposem una economia ramadera; de les ovelles i vaques, cada any en surten unes cries, que ens mengem, és el PIB. No cal deduir cap quantirat d'ovelles $\mathrm{i}$ vaques que moren de velles, perquè tampoc no comptem al PIB les cries que s'integren al tamat. Ês a dir, les pràctiques comptables seguides $a m b$ els recursos exhauribles suposen que els recursos no són exhauribles, sinó renovables, com si fossin vaques i ovelles. No cal amortizzar (o cal amortitzar moit poc) perquè es van fent descobriments. Si hi ha recursos exbatribles, algun dia s'acabaran els descobriments de nous jaciments.

Els economistes veuen tot decreixement de la producció $i$ àdhuc tot creixement inferior a la «línia de tendència» com la manifestació d'una crisi. Les seves propostes sobre la distribució (concretament sobre la limitació dels salaris) no es fan dins de la perspectiva de repartir una producció real permanentment minvada sinó des de la perspectiva de «sortir de la crisis. Si hi ha una deficiència de demanda efectiva que no permet d'utilitzar completament la capacitat productiva installada i la mà d'obra disponible, la despesa complementària, des d'aquest punt de vista de curt termini, tant se val que vingui del consum extra dels assalariats, com de despeses fetes en invertir, com dels ingtessos d'exportacions. La ideologia que diu que cal frenar els increments de salaris perquè la inversió pugi no és keynesianisme-de-curt-termini. A llarg termini, però, és a dir, considerant les variacions en la capacitat productiva installada i en la població activa, una despesa d'inversió, que a curt termini anima la demanda, permet, a llarg termini, d'ampliar l'oferta, si aquesta inversió és «productiva» (no és fer forats $\mathrm{i}$ tornar a omplir-los). Frenar els augments de salaris no és incompatible amb un augment de demanda efectiva si la inversió i les exportacions augmenten prou, i és evidentment compatible amb increments de la capacitat productiva si l'efecte és de fer créixer la inversió.

Molt sovint les propostes de frenar els salaris amb «pactes socials» (com les d'Okun, Tobin i, a nivell de divulgació, Rohatyn als Estats Units, 
i l'OECD i molts d'altres, a Europa) es fan també amb la intenció de frenar la inflació. Una economia amb creixement petmet un consensus, sense que la desigualtat entre classes desaparegui. Quan hi ha crisi econòmica pel cantó de l'oferta (per exemple quan, com hem vist a l'exemple brasiler, cada cop és més car energèticament disposar d'energia), les illusions de creixement continuat poden portat a la inflació, ja que, com deia Soddy, hom confon l'expansió de la capacitat productiva (l'expansió del capital físic) amb l'expansió del deute (del capital financet). Al final la inflació ja no fa de Iubricant social, sinó que introdueix gran incertesa en els plans d'inversió en fer pujar les taxes d'interès monetàries. Els empresaris s'endeuten sense saber què hauran de pagar realment després (ja que les taxes monetàries d'intetès contractades poden resultar altíssimes si la inflació disminueix després).

Per tant, les polítiques neocorporativistes molt sovint es posen com a objectiu manifest aturar la inflació. La base teòrica és la «corba de Phillips», que en principi fou una «llei» purament economètrica que indicava que inflació i desocupació estaven inversament relacionades. Quan, a la dècâda dels setanta, la inflació i l'atur van créixer simultàniament, això es va intetpretar com un desplaçament de la corba de Phillips, motivat per la inclusió de les expectatives d'inflació dins de les negociacions salarials. L'argument neocosporativista ha estat de reduir voluntàriament els augments de salaris per tal de reduit pressions sobre els costos i per tal d'augmentar l'ocupació. Mai no es presenta solament aquest argument de curt terme: s'afegeix sempre que la reducció de salaris tindrà efectes posi. tius sobre la inversió i per tant sobre el creixement.

Des del punt de vista metodològic, podxia semblar que els fets descrits per la corba de Phillips es presten molt més a una anàlisi collectivista que no pas individualista. Per exemple, la corba de Phillips pot ésser tradüda fàcilment a un llenguatge marxià-kaleckià: la inexistència d'un «exèrcit industrial de reserva» (a la dècada dels seixanta) va facilitar que els sindicats pressionessin sobre els beneficis, pressions que amb estructures oligopolístiques de mercat (o, el que és equivalent, amb una teoria de la formació de preus industrials per mark-ut sobre els costos variables a les empreses) poden ser trasiladades als preus. Aquesta anàlisi podia adoptar fàcil. ment un llenguatge durkheimià si la conclusió política que hom en treia no era pas la de permetre l'agudització d'un profit squeeze, controlant per exemple legalment els preus, sinó, a l'inrevés, controlant els salaris mitjançant acotds corforatius entre els grans actors socials. Des d'ambdós punts de vista (políticament oposats) les unitats d'anàlisi són collectius socials.

Per contra, des del punt de vista de l'individualisme metodològic, $s$ 'ha dit que: «Hi poden haver explicacions mig elaborades de fenòmens socials 
de gtan escala (per exemple, la inflació) en termes d'altres fenòmens socials de gran escala (per exemple, la plena ocupació); no arribarem, però, a explicacions fonamentals d'aquests fenòmens de gran escala fins que arribem a deduir-ne una explicació a partir de proposicions sobre les disposicions, creences, recursos $i$ intertelacions dels individus. (Els individus poden ser anònims i se'ls pot atribuir únicament disposicions típiques.)» (Watkins, 1959, cit. per Lukes, 1973.) És com si diguéssim (la comparació és de Lukes) que l'individualista metodològic, per tal d'explicat el funcionament de l'exèrcit, estudiaria les preferències individuals dels soldats $\longrightarrow$ del soldat típic- amb llur curiosa disposició a obeir ordres.

Així, en època de desocupació, si els salaris no baixen "prou» per permetre, pace la corba de Phillips, una reducció substancial de pressió sobre costos (una reducció, doncs, de la inflació), i si no baixen prou per permetre -a llarg termini- un augment d'inversió que augmenti la capacitat productiva, això s'ha d'explicar analitzant decisions racionals d'obrers típics i empreses típiques que maximitzen o minimitzen alguna cosa. En canvi, els «collectivistes metodològics» potser farien servir les normes socials del collectiu de treballadors i del collectiu de capitalistes, el poder monopolístic als mercats de productes, $i$ fins $i$ tot conceptes com consciència de classe i lluita de classes (cf. Sawyer, 1982, per un enfocament kaleckià de la macroecononornia).

Durkheim (1902) feia aquesta predicció: la divisió del treball crea conflictes que podrien tornar-se funcionals per a l'estabilitat de la societat capitalista si la societat $i$ l'Estat s'organitzen a la manera corporativista. Aquest corporativisme era compatible amb la representació parlamentària de base territorial, per sufragi univetsal, complementada per la representació corporativa de diferents intezessos professionals, que establirien acords per solucionat els conflictes derivats d'una economia de tnercat, de la divisió del treball, de l'individualisme «anòmic», és a dir, desproveit de les normes tradicionals de convivència. Per a Durkheim hi havia fets $\mathrm{i}$ institucions socials irreduïbles a preferències $\mathrm{i}$ decisions individuals.

La concepció corporativista de la societat és diferent de la concepció liberal-individualista. La primera posa èmfasi en l'aspecte social de les persones $\mathrm{i}$ en l'harmonització dels interessos dels diversos collectius als quals pertanyen, mitjançant negociacions fora del mexcat. La segona s'expressa en un individualisme no solament metodològic sinó ontològic i creu en l'harmonització dels interessos individuals mitjançant l'operació de la «mà invisible» al metcat. Els partidaris de «pactes socials» encaixen molt millor en la concepció corporativista, malgrat que siguin, molts d'ells, economistes.

Podríem també pensar que, per a fet macroeconomia, no cal cap discus- 
sió metodològica prèvia, en el sentit que la macroeconomia podria establit Ileis purament economètriques. Per exemple, que les unitats bàsiques d'anàlisi social siguin els individus o els collectius sembla una qüestió supèrflua si pensem en els estudis de Kuznets (1966) en què correlaciona augments de PIB i proporció de la Inversió Neta (magnituds agafades de la Comptabilitat Nacional). Un altre exemple fóta l'extrapolació dels suposats cicles Kondratiev.

Ara bé, per establir les magnituds de la Comptabilitat Nacional ens cat agregar inputs i productes, $i$ per tant necessitem donar-los valors. Els macroeconomistes no poden, doncs, prescindir de cap manera de la microeconomia. La qüestió no és explicar els fonaments microeconòmics de les accions d'individus, ja que aquestes accions potser s'expliquen més bé si eís considerem com a membres de collectius socials, tal com les peculiars accions dels soldats s'entenen únicament si entenem els reglaments i els càstigs de l'exèrcit. La qüestió és que la macroeconomia necessita preus per agregar les magnituds macroeconòmiques $i$ els preus surten únicament de la microeconomia.

En una economia ricardiana senzilla, amb un sol producte, «biat», que serveix també de llavor, podriem donar el Producte Total, el Consum, la Inversió (en la forma de llavor), els Salaris, els Guanys dels arrendataris capitalistes i les Rendes dels terratinents, tot en unitats de blat. A més, podríem suposar que d'un any a l'altre baixa el Consum i augmenta la Inversió (una part més gran de la collita és emprada com a llavor); podríem estudiar aleshores com augmenta el Producte Total, i calcular la Taxa de Rendiment de la Inversió (una mena de Taxa d'Interès) que presumiblement ha compensat el sacrifici de Consum actual a canvi d'un augment de Consum posterior, sense malbaratar, en aquest cas, cap recurs exhaurible.

Ara bé, les Comptabilitats Nacionals teals fan servir els preus, perquè no hi ha cap altra manera de sumar productes heterogenis. La macroeconomia ensopega, doncs, amb la qüiestió dels preus dels recursos exhauribles. No pot haver-hi macroeconomia a les economies monetàries sense microeconomia crematística, perquè la Comptabilitat Nacional es fa amb preus, que seran simplement els del mercat o (en el cas dels recursos exhauribles) potser uns preus corregits tenint en compte els costos d'oportunitat èticosubjectius de la utilització actual que sacrifica la utilització futura.

Pot semblar, però, que, per exemple, per analitzar el repartiment de l'Ingrés Total entre assalariats i capitalistes és més fructífer d'estudiar la Whita de classes (o l'harmonia de classes, assolida mitjançant acords corporatius) que no pas recórrer a l'estudi d'accions individuals d'intercanvi. Aquesta perspectiva, que considera els collectius socials com a unitats bà- 
siques d'anàlisi, porta, per exemple, a recomanacions sobre "polítiques de rendes» amb acords entre govern, patronal i sindicats per tal de frenar la inflació i per tal d'augmentar les expectatives de guany i, per tant, per tal d'augmentar la inversió, la qual cosa pot fer augmentar la producció (tant a curt com a llarg terme). Es fan crides a la "solidaritat nacional» (i no pas a la «mà invisible», d'una banda, ni a la lluita de classes, d'altra banda) per tal de «sortir de la crisi». Em sembla que la ideologia socialdemòcrata ( $i$, és clar, eurocomunista) ha estat una barreja de corporativisme dukheimià (laic, i no antiparlamentari) amb macroeconomia keynesiana.

El corporativisme socialdemòcrata és, tanmateix, anterior a la dècada dels trenta (Charles Maier, 1975). La socialdemocràcia, nascuda de la lluita de classes, té, però, un problema de legitimitat política si es declara corpotativista i, per aquesta taó, li ha estat convenient el suport de la macroeconomia.

La consideració dels recursos exhauribles fa néixer dubtes bàsics sobre les definicions de les magnituds macroeconòmiques ("producción, per exemple) i per tant fa mal a la ideologia de la socialdemoctàcia neocorporativista, que vol legitimar la desigualtat mentre s'espera el creixement, en qüestionar quelcom tan elemental com la manera de construir la Comptabilitat Nacional. 


\section{BIBLIOGRAFIA}

Aguilar, Salvador: «El asociacionismo empresarial en la transición postfranquista», Crónica de Información Laboral, núm. 17.18, juliol-agost, 1983.

Alemann, Ulrich v. \& R. G. Heinze, eds.: Verb̈̈nde und Staat. Vom Pluralismus zum Korporatismus, Opladen, 1979.

Amsden, Jon: Collective bargaining and class conflict in Spain, Weindenfeld \& Nicholson, Londres, 1971.

Anderson, Charles: Tbe political economy of modern Spain, Chicago, U.P., 1970.

Aunós, Eduardo: La organización corporativa del trabajo, Consejo Superior de Trabajo, Cometcio e Industria, Madrid, 1927.

Aznar, Severino, Estudios económico-sociales, Instituto de Estudios Políticos, Madrid, 1946 (pròleg de José Larraz).

Azpiazu, Joaquín (S. J.): El estado corporativo, Edit. Navarra, Pampiona, 1937 (amb bibliografia austríaca i alemanya).

Cawson, Alan: «A preliminary bibliography of modern corporatism», «Sussex Working Papers in Corporatism», núm. 1, abril 1983.

Connolly, W., The Terms of Political Discourse, 2a. ed., Martin Robertson, Oxford, 1983.

Diamant, Alfred: Austrian Catbolics and the First Republic, Princeton, 1960.

Estradé, A. \& J. A. Casado: «El nuevo corporativismo: una salida capitalista ante la crisis», «Transición» (Barcelona), núm. 14, novembre 1979.

Fraga Iribarne, Manuel, «La reforma de la emptesa», a El desarrollo político, Grijalbo, Barcelona, 1972.

Giner, S., «España entre el viejo y el nuevo corporatismo», «La Vanguardia», 29 d'abril de 1982.

Giner, S. \& E. Sevilla: «Spain: from Corporatism to Corporatism», en A. Williams (ed.), Southern Europe transformed, Harper \& Row, 1984.

Grenner, Kari Heinz, Wirtschattsliberalismus und Katolische Denkens, J. P. Bachem, Köln, 1967 (Adam Müller, Baader, Ketteler, Reichensperger, Hitze, Pesch).

Gulick, Charles A.: Austria from Habsburg to Hitler, University of California Press, Berkeley, 1948.

Hayek, F. A. v.: The constitution of liberty, Routledge \& Kegan Paul, Londres, 1960. 
Jones, Aubrey: The New Inflation, Penguin Books, 1973.

Kastendiek, Hans: «Neokorporatismus?», «Prokla», núm. 38, 1980.

Lang, W.: «Spanien rach Franco: vom autoritären zum liberalen Korporatis* mus?», en Ulrich v. Alemann (Hrsg.): Neokorporatismus, Campus Verlag, Frankfurt, 1981.

Lehmbruch, G. \& Ph. Schmitter, eds., Patterns of Corporatist Policy Making, Sage, Londres, 1982.

Linz, Juan: «A century of politics and interests in Spain», in S. Berger, ed., Organizing interests in Western Europe, Cambridge U.P.

Maier, Charles, Recasting bourgeois Europe, Princeton, 1975.

Matavall, J. M., La politica de la transición, Taurus, Madrid, 1982.

Martín-Artajo, Alberto \& Cuervo, Máximo: Doctrina social católica de León XIII y Pio XI, Eabor, Barcelona, 1933. (Probleg de Ángel Herrera Otia).

Martínez Alier, J.: «Notas sobre el franquismo», «Papers»: Revista de Sociologia, núm. 8, Barcelona, 1978.

Martínez Alier, J.: «EI Pacto de la Moncloa. La lucha sindical y el nuevo corporativismo», "Cuadernos de Ruedo Ibérico», núm. 58-60, 1977.

Martínez Alier, J.: «El viejo y el nuevo corporativismo», «El País», 5 desembre 1981.

Moyano, Eduardo \& Manuel Pérez Yruela: «El estado de la cuestión en el debate neocorporativista" (Ms., 1984).

Moyano, E.: «Corporatismo y agticultura» (tesi doctoral, Esc. Ing. Agr., Universidad de Cótdoba, 1983).

Müllet, Alberto \& Azpiazu, Joaquín: La politica corporativa. Ensayo de organización corporativa, Razón y Fe, Madrid, 1935.

Nell-Breuning, Otto: Die soziale Enzyklika, Katholische Tag Verlag, Köln, 1932.

Pétez Díaz, V., «Políticas económicas y pautas sociales en la España de la transición: la doble cara del neocorporatismo* (Ms., 1984).

Pérez Díaz, V., «Orientaciones políticas de los obreros españoles hoy», «Sistema», núm. 29-30, 1979.

Pike, F. \& T. Stritch, eds.: The New Corporatism. Social Political Structures in the Iberian World, Notre Dame, 1974.

Pradera, Víctor: El estado nuevo (1937), 3a. ed., Cultura española, Madrid, 1941 (ptòleg de J. M. Pemán).

Roca, fordi: «Els pactes socials: cap a un nou corpozativisme? El cas de l'Estat espanyol, 1978-83" (tesina de llicenciatura, UAB, Bellaterra, Batcelona, 1984).

Rohatyn, Felix G., «Time for a Change», «New York Review of Books», 18 agost 1983.

Sáez Alba, A.: La Asociación Católica Nacional de Propagandistas, Ruedo Ibérico, París, 1974.

Schütz, Roland: «Verbände und Verbandsmacht in Spanien. Neokorporative Strukturen bei det Artikulation und Repräsentation von Gruppeninteressen in Spanien» (Ms. octubre 1983).

Secretariado de la Junta Nacional de Semanas Sociales: Hacio uno más justa dis- 
Velles ideologies i noves realitats corporativistes

tribucion de la riqueza (IX Semana), Madrid, 1950 (Azpiaza, Aznar, Herrera Oria i l'economista Torres Martínez i d'altres).

Secretariado de la Junta Nacional de Semanas Sociales, El trabajo (XII Semana), Madrid, 1952 (Larraz, Fraga, Glz. Menéndez-Reigada, els economistes Inza y Fuentes Quintana i d'altres).

Shonfield, A.: Modern capitalism, Oxford U.P., 1965.

Wiarda, H. J.: *Corporatism and Development in the Iberic-Latin World», in Pike \& Stritch, 1974. 